\title{
The Estimation of Adenosinetriphosphate
}

\author{
By S. L. ROWLES* AND L. A. STOCKEN \\ Department of Biochemistry, University of Oxford
}

(Received 8 May 1950)

In the course of a study of the distribution of acidsoluble phosphates in the fatty livers of carbon tetrachloride-poisoned guinea pigs a marked increase was observed in the amount of the adenosine polyphosphate (APP) fraction (Ennor \& Stocken, 1948). In this earlier work it was also indicated that the method recommended by Le Page \& Umbreit (1945) and Le Page (1946) for the estimation of nitrogen : $7 \mathrm{~min}$. labile phosphorus : pentose ratios, used to establish the composition of APP mixtures, was unsatisfactory, and that enzymic methods might prove more reliable. It was apparent that before we could apply this technique to liver fractions it was essential to investigate the action of enzymes on pure adenosinetriphosphate (ATP).

A recent paper by Bailey (1949) has largely anticipated our findings but, whilst we are in agreement with most of his results, we have some observations which amplify and others which differ from his.

\section{EXPERIMENTAL}

\section{Materials and methods}

Myosin adenosinetriphosphatase was prepared from rabbit muscle (usually the psoas) as described by Bailey (1942).

Myokinase. The procedure described by Colowick \& Kalckar (1943) was followed as far as the removal of inert protein after heat treatment in acid solution. The filtrate was half saturated with $\left(\mathrm{NH}_{4}\right)_{2} \mathrm{SO}_{4}$ at $0^{\circ}$ and the precipitate discarded. The protein obtained by complete saturation was dissolved in a small volume of water and dialysed at $0^{\circ}$ against $2 \%(\mathrm{w} / \mathrm{v})\left(\mathrm{NH}_{4}\right)_{2} \mathrm{SO}_{4}$ as described by Kalckar (1943).

Yeast pyrophosphatase. A suitable preparation of this enzyme was obtained as follows: the initial incubation of yeast (Distillers' Co. Ltd.) was carried out according to Bailey \& Webb (1944), without re-extraction of the residue obtained after centrifugation. The supernatant fluid was filtered through paper pulp and cooled in an ice-salt mixture; an equal volume of ice-cold acetone was then slowly added with stirring at such a rate that the temperature did not rise above $0^{\circ}$. The precipitate (from $500 \mathrm{~g}$. yeast) was centrifuged off, dissolved in about $100 \mathrm{ml}$. of water and brought to $60 \%$ saturation with $\left(\mathrm{NH}_{4}\right)_{2} \mathrm{SO}_{4}$ at $0^{\circ}$. The resulting precipitate was dissolved in water and dialysed against three changes of 31 . of water at $0^{\circ}$. The resultant solution $(0.1 \mathrm{ml}$.) liberated $75 \mu \mathrm{g}$. orthophosphate $\mathrm{P}$ from $\mathrm{Na}_{4} \mathrm{P}_{2} \mathrm{O}_{7}$ in $10 \mathrm{~min}$. at $37^{\circ}$.

Yeast hexokinase. We have prepared this enzyme by the methods of Bailey \& Webb (1948) and of Berger, Slein,

* Present address: Medical Research Council Dental Research Unit, King's College Hospital Medical School, London, S.E. 5.
Colowick \& Cori (1946); but since, as Bailey (1949) points out, the former method is a formidable task we abandoned it in favour of that described by the American authors. We found it unnecessary for our purpose to proceed beyond stage 3 of their preparation.

Potato apyrase. In the earlier work the method of Kalckar (1944) without ethanol fractionation was employed, and more recently we have used that of Krishnan (1949).

Adenosinetriphosphate. ATP was obtained as described by Le Page(1945), except that we have found little advantage is to be gained by $\mathrm{Mg}$ anaesthesia. For the preparation of ATP containing ${ }^{32} \mathrm{P}$ we used muscle from rabbits which had been intravenously injected with carrier-free radioactive phosphate (cf. Dounce, Rothstein, Beyer, Meier \& Freer, 1948).

ATP solutions. As Bailey (1949) points out, there is a considerable loss of irrecoverable ATP by adsorption when the $\mathrm{Ba}$ salt is decomposed with sulphate; this can be avoided practically completely by means of a suitably prepared ionexchange resin. Amberlite IR-100 H (2 g.), in a column $16 \times 0.5 \mathrm{~cm}$., was converted to the acid form by $5 \mathrm{~N}-\mathrm{HCl}$ and then washed with glass-distilled water until the effluent was free from chloride. $\mathrm{Ba}_{2}$ ATP (200 mg.), dissolved in $5 \mathrm{ml}$. of ice-cold $\mathrm{N}-\mathrm{HCl}$, was made up to $50 \mathrm{ml}$. with glass-distilled water. Two samples of $20 \mathrm{ml}$. were taken, the first put through the resin column and washed through with $40 \mathrm{ml}$. water, neutralized and made up to $100 \mathrm{ml}$., and the second precipitated with sulphate in the usual way and also made up to $100 \mathrm{ml}$. In both cases the temperature throughout was $0^{\circ}$.

The recoveries of inorganic and total phosphate by $\mathrm{Ba}$ precipitation were 92 and $84 \%$, respectively, and by removal with the resin 100 and $99 \%$. We have not observed any decomposition of ATP, although in our case we used the acid form of the resin, whereas Bailey (1949) used the $\mathrm{Na}$ salt.

Inorganic phosphate was estimated as described by Berenblum \& Chain (1938).

Measurement of radioactivity. In the Berenblum \& Chain method orthophosphate only is extracted from the unknown solution as the phosphomolybdate complex and it is thus possible to estimate both the radioactive and total orthophosphate in the same sample. The isobutanol extract was made up to a convenient volume and ${ }^{32} \mathrm{P}$ estimated by means of a liquid counter (Veall, 1948). A suitable sample was then reduced with $\mathrm{SnCl}_{2}$ for colorimetric determination of the total P.

Incubation conditions. All the enzymic hydrolyses were carried out in a duplicate series of $10 \mathrm{ml}$. graduated tubes, each containing $2.0 \mathrm{ml}$. of the appropriate buffer, $1.0 \mathrm{ml}$. of ATP and $0.5 \mathrm{ml}$. of enzyme solution. The essential cations were added to the buffers before use. The reactions were stopped, except in the case of hexokinase where $\mathrm{HCl}$ was used, with $2.0 \mathrm{ml}$. of $30 \%(\mathrm{w} / \mathrm{v})$ trichloroacetic acid at intervals of $5,10,15,30$ and $60 \mathrm{~min}$. The tubes were then 
Table 1. Analysis of laboratory preparations of adenosinetriphosphate

(All values expressed as percentage of total organic phosphorus. In Exps. 8, 8a and $8 b$ all analyses were carried out 18, 24 and 33 months, respectively, from date of preparation.)

\begin{tabular}{|c|c|c|c|c|c|c|c|}
\hline \multirow[b]{2}{*}{$\begin{array}{l}\text { Exp. } \\
\text { no. }\end{array}$} & \multicolumn{2}{|c|}{ Chemical analysis } & \multicolumn{5}{|c|}{ Enzymic analysis } \\
\hline & Free P & $\begin{array}{l}10 \text { min. } \\
\text { labile } P \\
\text { in } \mathrm{N}-\mathrm{HCl} \\
\text { at } 100^{\circ}\end{array}$ & $\begin{array}{c}\text { Adenosine- } \\
\text { triphos- } \\
\text { phatase }\end{array}$ & $\begin{array}{c}\text { Adenosine- } \\
\text { triphos- } \\
\text { phatase + } \\
\text { myokinase }\end{array}$ & $\begin{array}{c}\text { Potato } \\
\text { apyrase }\end{array}$ & $\begin{array}{c}\text { Yeast } \\
\text { hexokinase }\end{array}$ & $\begin{array}{l}\text { Yeast pyro- } \\
\text { phosphatase }\end{array}$ \\
\hline 1 & 1.9 & $68 \cdot 5$ & $31 \cdot 0$ & $62 \cdot 0$ & - & - & 0.2 \\
\hline 2 & $1 \cdot 7$ & $64 \cdot 8$ & $30 \cdot 0$ & $61 \cdot 5$ & $64 \cdot 4$ & $30 \cdot 6$ & 0 \\
\hline 3 & 0.9 & $66 \cdot 2$ & $28 \cdot 5$ & $56 \cdot 2$ & $63 \cdot 8$ & $28 \cdot 0$ & $1 \cdot 2$ \\
\hline 4 & 0.45 & $66 \cdot 9$ & $29 \cdot 9$ & $62 \cdot 0$ & $66 \cdot 0$ & $28 \cdot 6$ & $0 \cdot 4$ \\
\hline 5 & 0.5 & $66 \cdot 7$ & $28 \cdot 1$ & $56 \cdot 8$ & $68 \cdot 2$ & - & - \\
\hline 6 & $3 \cdot 9$ & $63 \cdot 8$ & $25 \cdot 8$ & $56 \cdot 2$ & $60 \cdot 7$ & - & - \\
\hline 7 & $4 \cdot 2$ & $65 \cdot 8$ & $28 \cdot 9$ & $58 \cdot 6$ & - & - & $3 \cdot 8$ \\
\hline 8 & $3 \cdot 4$ & $65 \cdot 2$ & $25 \cdot 4$ & $52 \cdot 5$ & - & - & 0.8 \\
\hline $8 a$ & $3 \cdot 6$ & $63 \cdot 8$ & $25 \cdot 8$ & $52 \cdot 8$ & $58 \cdot 6$ & - & $2 \cdot 3$ \\
\hline $8 b$ & $3 \cdot 7$ & 一 & - & - & - & - & $2 \cdot 7$ \\
\hline
\end{tabular}

cooled in ice, made up to volume, protein removed by filtration where necessary and samples taken for analysis. Except that the amounts of ATP in each tube were about one-tenth of those used by Bailey (1949) and that we worked at $37^{\circ}$ instead of $25^{\circ}$ with myosin and myokinase, the conditions did not vary from those generally employed, i.e. yeast pyrophosphatase and yeast hexokinase, veronalacetate $\mathrm{pH} 7 \cdot 2,38^{\circ}$; potato apyrase, succinate $\mathrm{pH} 6.5$, $28^{\circ}$; adenosinetriphosphatase with or without myokinase, glycine- $\mathrm{NaOH}, \mathrm{pH} 9 \cdot 1,37^{\circ}$.

\section{RESULTS}

We are in complete agreement with Bailey (1949) that the amounts of phosphate liberated from ATP by myosin, and by myosin + myokinase, are approximately $90 \%$ of the theoretical values based on acidlabile and total phosphorus figures, and that the apyrase-labile phosphorus is very close to that obtained by acid hydrolysis (Table 1). We have found that hexokinase gives the same estimate as myosin. This latter finding, together with the fact that our concentrations were so much lower than his, did not, in our opinion, conform with Bailey's suggestion that removal of substrate from the system by coprecipitation with calcium orthophosphate might account for the lower values given by myosin. We therefore attempted to decide this point by means of ${ }^{32} \mathrm{P}$-labelled ATP which allows the direct estimation of phosphate liberated from ATP in the presence of a large excess of added inactive phosphate.

A series of tubes were set up as follows: $4.0 \mathrm{ml}$. of glycine buffer containing varying amounts of calcium chloride, $2.0 \mathrm{ml}$. of radioactive ATP solution ( $\equiv 19 \mu \mathrm{g}$. myosin-labile $\mathrm{P}$ ), $0.5 \mathrm{ml}$. of myosin and $2.0 \mathrm{ml}$. of water containing 0,200 or $400 \mu \mathrm{g}$. orthophosphate $P$. After $20 \mathrm{~min}$. incubation at $37^{\circ}$ the reaction was stopped with $1.5 \mathrm{ml}$. of $50 \%(\mathrm{w} / \mathrm{v})$ trichloroacetic acid. The filtered solution (8.0 ml.) was shaken with $3.0 \mathrm{ml}$. of $5 \%(w / v)$ ammonium molybdate, $0.5 \mathrm{ml}$. of $\mathrm{N}$-sulphuric acid and $16 \mathrm{ml}$. of isobutanol. The isobutanol layer was washed twice with $10 \mathrm{ml}$. of $\mathrm{N}$-sulphuric acid, made up to $20 \mathrm{ml}$. with ethanol and the ${ }^{32} \mathrm{P}$ content determined. The results (Table 2) indicate, as Bailey suggests, that

Table 2. Effect of added inorganic phosphate on the extent of enzymic breakdown of radioactive $A T P$ caused by adenosinetriphosphatase and adenosinetriphosphatase + myokinase

(ATP equivalent to $19 \mu \mathrm{g}$. adenosinetriphosphataselabile $P$ used in each experiment. Radioactivity figures are based on a total count of not less than 10,000 for each sample.)

\begin{tabular}{|c|c|c|c|}
\hline \multirow{2}{*}{$\begin{array}{l}\text { Final } \\
\text { concen- } \\
\text { tration } \\
\text { of Ca } \\
\left(\times 10^{-4} \mathrm{M}\right)\end{array}$} & \multicolumn{2}{|c|}{$\begin{array}{l}\text { Radioactivity of inorganic } \\
\text { P released from ATP, } \\
\text { expressed as \% of that } \\
\text { released in absence of } \\
\text { added inorganic P }\end{array}$} & \multirow[b]{2}{*}{$\underset{\text { used }}{\text { Enzymes }}$} \\
\hline & $\begin{array}{l}200 \mu \text { g. } P \\
\text { added }\end{array}$ & $\begin{array}{l}400 \mu g . P \\
\text { added }\end{array}$ & \\
\hline $7 \cdot 7$ & $\begin{array}{l}97 \cdot 5 \\
97 \cdot 8\end{array}$ & $\left.\begin{array}{l}96 \cdot 7 \\
97 \cdot 8\end{array}\right)$ & \multirow{3}{*}{$\begin{array}{l}\text { Adenosinetriphos- } \\
\text { phatase }\end{array}$} \\
\hline 11.7 & $\begin{array}{l}97 \cdot 0 \\
98 \cdot 4\end{array}$ & $\left.\begin{array}{l}95 \cdot 5 \\
92 \cdot 3\end{array}\right\}$ & \\
\hline $23 \cdot 4$ & $\begin{array}{l}91 \cdot 0 \\
90 \cdot 6\end{array}$ & $\begin{array}{l}87 \cdot 0 \\
84 \cdot 7\end{array}$ & \\
\hline $11 \cdot 7$ & $\begin{array}{c}100 \\
99 \cdot 4\end{array}$ & $\begin{array}{l}95 \cdot 0 \\
94 \cdot 8\end{array}$ & $\begin{array}{l}\text { Adenosinetriphos- } \\
\text { phatase + myo- } \\
\text { kinase }\end{array}$ \\
\hline
\end{tabular}

the rate of the enzymic reaction is determined by both calcium and phosphate concentration, but it will be noted that the addition of ten times as much orthophosphate as is released from the ATP only produced a $3 \%$ inhibition with the calcium concentration used in the other enzymic experiments. It seems unlikely, therefore, that coprecipitation of $\mathrm{Ca}_{2}$ ATP with calcium phosphate produced in the course of the reaction can be responsible for the low 
analytical values given by myosin or myosin + myokinase.

A further experiment with radioactive ATP, in which apyrase was compared with myosin + myokinase, agreed with the earlier findings. The amount of phosphate liberated by myokinase + myosin was $95 \%$ of the apyrase figure both by radioactive and colorimetric estimation.

Although we have had some samples of ATP which decomposed giving inorganic pyrophosphate, we do not agree that this is necessarily true for all preparations. In particular, we have analysed one specimen of $\mathrm{Ba}_{2} \mathrm{ATP}$, kept at room temperature in a desiccator for a period of 2.75 years and found that, although the inorganic phosphate has increased, the pyrophosphate content at the end of this time was only $3.5 \%$ of the acid-labile $\mathbf{P}$. This figure is to be compared with $41 \%$ as found by Bailey after 2 years' storage at room temperature.

\section{DISCUSSION}

In an earlier paper from this laboratory (Ennor \& Stocken, 1948) it was concluded that more specific methods than the determination of nitrogen : pentose : phosphate ratios were required for the estimation of ATP and ADP in tissue extracts. Recent work by Bailey (1949) and by us on the analysis of ATP by enzymic methods confirms this opinion. On the other hand, it should be noted that Le Page \& Potter (1949), presumably following the Le Page \& Umbreit (1945) technique, maintain the view that laboratory preparations are pure, and deny that decomposition to inorganic pyrophosphate necessarily takes place in all samples of ATP. We are in agreement with this latter finding, but consider that the different solubilities of the barium salts cannot be relied on to give a complete separation of pyrophosphate from ATP. We suggest that there is a considerable risk of loss of barium pyrophosphate by coprecipitation with $\mathrm{Ba}_{2}$ ATP even though the solubility is not exceeded, and that it is essential to employ the specific pyrophosphatase as described by Bailey. Except in specimens analysed immediately after preparation, we have always found a small amount of inorganic pyrophosphate, but have not encountered the degree of decomposition observed by Bailey.

Apart, however, from the question of pyrophosphate there still remains a discrepancy between the values obtained by hexokinase, myosin, myosin + myokinase on the one hand, and apyrase and acid hydrolysis on the other. We are unable to accept the suggestion that precipitation of $\mathrm{Ca}_{2}$ ATP or inactivation of the enzyme is responsible for the lower value obtained with myosin, since both these points were tested experimentally. The fact that hexokinase also gives a low value supports this view. It seemed possible to us that the impurity might be an anhydride of ATP:

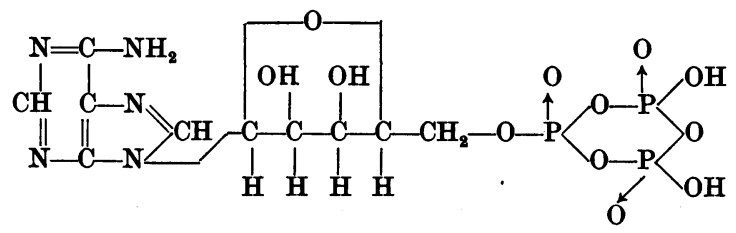

and we hoped that paper chromatography would yield some evidence on this point, but as yet we have had no success. It is of interest in this connexion that Michelson \& Todd (1949) have also speculated on the existence of this compound. In an attempt to prepare the branched-chain isomer of ATP by unambiguous synthesis the final product obtained was the natural isomer, a result which they could only explain by postulating the intermediate formation of the metaphosphate.

It appears, therefore, that the method at present used for the preparation of ATP fails to give either an initially pure compound or a mixture which is indefinitely stable. It also seems certain that chemical methods alone are inadequate to detect contamination with small amounts of closely related substances. We are of the opinion that enzymes must be employed to obtain the highest degree of accuracy and that the most convenient of these are myosin and myokinase.

\section{SUMMARY}

1. It has been shown that myosin, myosin + myokinase and hexokinase give lower values than apyrase or acid hydrolysis when used to estimate the labile groups of laboratory preparations of adenosinetriphosphate.

2. A suggestion is made that a contaminant organo-metaphosphate might be responsible for this difference.

3. It is recommended that myosin and myokinase be used for the assay of adenosinetriphosphate.

We wish to express our gratitude to the Department of Scientific and Industrial Research for a grant to one of us (S. L. R.) and to Mr T. Gascoyne for skilled technical assistance. 


\title{
REFERENCES
}

Bailey, K. (1942). Biochem. J. 36, 121.

Bailey, K. (1949). Biochem. J. 45, 479.

Bailey, K. \& Webb, E. C. (1944). Biochem. J. 38, 394.

Bailey, K. \& Webb, E. C. (1948). Biochem. J. 42, 60.

Berenblum, I. \& Chain, E. (1938). Biochem. J. 32, 295.

Berger, L., Slein, M. W., Colowick, S. P. \& Cori, C. F. (1946). J. gen. Physiol. 29, 379.

Colowick, S. P. \& Kalckar, H. M. (1943). J. biol. Chem. 148, 117.

Dounce, A. L., Rothstein, A., Beyer, G. T., Meier, R. \& Freer, R. M. (1948). J. biol. Chem. 174, 361.

Ennor, A. H. \& Stocken, L. A. (1948). Biochem. J. 42, 549.

Kalckar, H. M. (1943). J. biol. Chem. 148, 127.

Kalckar, H. M. (1944). J. biol. Chem. 153, 355.
Krishnan, P. S. (1949). Arch. Biochem. 20, 261, 272.

Le Page, G. A. (1945). In W. W. Umbreit, R. H. Burris \& J. F. Stauffer. Manometric Techniques and Related Methods for the Study of Tissue Metabolism. Minneapolis: Burgess Publishing Co.

Le Page, G. A. (1946). Amer. J. Physiol. 146, 267.

Le Page, G. A. \& Potter, V. R. (1949). J. biol. Chem. 179, 1229.

Le Page, G. A. \& Umbreit, W. W. (1945). In W. W. Umbreit, R. H. Burris \& J. F. Stauffer, Manometric Techniques and Related Methods for the Study of Tissue Metabolism. Minneapolis: Burgess Publishing Co.

Michelson, A. M. \& Todd, A. R. (1949). J.chem. Soc. p. 2487. Veall, N. (1948). Brit. J. Radiol. 21, 347.

\section{ADDENDUM}

\section{The problem of adenosinetriphosphate breakdown}

\author{
BY K. BAILEY \\ Biochemical Laboratory, University of Cambridge
}

The extensive use of adenosinetriphosphate (ATP) in the investigation of biological reactions is sufficient justification for the present attempt to coordinate the findings of Rowles \& Stocken (1950) with those already reported (Bailey, 1949). The two investigations are now seen to be quite similar in scope and design, although this is a fortuitous circumstance. Most of the findings are in agreement, and it is necessary to discuss only two points which Rowles \& Stocken have raised and which might be misinterpreted.

(1) The limit of ATP breakdown with purified myosin. Rowles \& Stocken confirm that with myosin adenosinetriphosphatase the free phosphate liberated from ATP is always less than $50 \%$ of the acid-labile $\mathbf{P}$. They incline to the view that this is due to the presence of an impurity and not to a retardation of the reaction rate by adsorption of ATP on calcium phosphate during the later stages of the reaction. Under the conditions earlier employed, which are somewhat different from those used here, the rate of splitting in presence of large amounts of free phosphate was always slow. It was not suggested that this was necessarily the cause of the eventual cessation of hydrolysis, but rather as a disadvantage of the method. Other experiments did, in fact, lead to the view that the presence of an impurity could not be ruled out. The present finding of Rowles \& Stocken, that ATP is degraded to a comparable extent by myosin adenosinetriphosphatase and by yeast hexokinase, considerably strengthens this latter view. Under some conditions of incubation, however, it is still true that the later stages of the reaction proceed rather slowly, and it may well be that the incubation conditions of Rowles and Stocken are to be preferred.

(2) The decomposition of $A T P$ on storage. It was earlier emphasized that the factors governing the breakdown of salts of ATP had not been fully determined, and several may be involved, e.g. water content, alkalinity of specimen, presence of contaminating metal ions, etc. The complex nature of these factors can be judged from the following consideration. A dibarium salt, if originally at a slightly alkaline $\mathrm{pH}$, will break down predominantly to inorganic pyrophosphate. The acid groups thus released will cause a progressive acidification, and the pattern of breakdown may thus be altered. Both the undecomposed ATP and the inorganic pyrophosphate may then give rise to free phosphate. It should be noted that the inorganic pyrophosphate content of stored specimens was expressed (Bailey, 1949) as a percentage of the acid-labile $P$ remaining, not of labile $\mathbf{P}$ plus free phosphate, which would give a truer measure of breakdown. This method of expression was used because the free phosphate contained in some of the ATP samples then available was unknown at the time of their actual preparation. Dr Stocken has kindly submitted two of his stored specimens which have now been analysed side by side with a preparation made in Cambridge (Table 1).

These samples were converted to the sodium salt by precipitation of barium as sulphate, and it is likely, as Rowles \& Stocken point out, that the recovery of inorganic pyrophosphate and of free phosphate is greater than that of nucleotide $P$. The figures tend, therefore, to exaggerate the extent of breakdown. It will be seen that the inorganic 
Table 1. Breakdown of stored samples of barium ATP

( $P$ values expressed as percentage of acid-labile + free $P$.)

\begin{tabular}{|c|c|c|c|c|c|}
\hline Preparation $\quad \ldots$ & $\cdots$ & Oxford & Oxford & Cambridge & Commercial \\
\hline Type of salt & & Dibarium & $\underset{5.4}{\text { Dibarium }}$ & Monobarium & Monobarium \\
\hline $\begin{array}{l}\text { Water content (\%) } \\
\text { Temp. of storage }\end{array}$ & & $\begin{array}{l}\text { R.o } \\
\text { Room }\end{array}$ & Room & $\begin{array}{c}11 \cdot 7 \\
0^{\circ}\end{array}$ & $\begin{array}{c}11 \cdot 2 \\
0^{\circ}\end{array}$ \\
\hline Age of specimen (yr.) & & $2 \cdot 75$ & 1 & $1 \cdot 3$ & $>2$ \\
\hline Free $\mathrm{PO}_{4}$ & & 10 & 13 & 12 & 26 \\
\hline Inorganic pyrophosphate & & 6 & 6 & $\mathbf{5}$ & 19 \\
\hline
\end{tabular}

pyrophosphate content is not as high in the Oxford and Cambridge samples as might have been expected from the rate of breakdown of some laboratory and commercial specimens previously investigated. Nevertheless, the amount of inorganic phosphate is very considerable, and in the Cambridge sample, at least, has risen from nil to $12 \%$ of the acid-labile $P$ in less than a year and a half. It was earlier sug- gested (Bailey, 1949) that the presence of free phosphate in reputable ATP specimens was itself indicative of breakdown, and this statement is still valid. A test for inorganic pyrophosphate also needs to be made, and this has been greatly facilitated by the simple method which Rowles \& Stocken have evolved for the preparation of yeast inorganic pyrophosphatase.

\title{
REFERENCES
}

Bailey, K. (1949). Biochem. J. 45, 479.

Rowles, S. L. \& Stocken, L. A. (1950). Biochem. J. 47, 489.

\section{Studies on the Skeletal Tissues}

\section{THE DEGREE OF CALCIFICATION OF SELECTED MAMMALIAN BONES}

\author{
By S. M. WEIDMAN AND H. J. ROGERS \\ Biological Research Unit, Dental School and Hospital, Leeds
}

(Received 17 April 1950)

Considerable attention has been paid to the composition of the inorganic part of the skeletal tissues, but little knowledge of the organic matrix upon which these salts are deposited exists. Marked differences between the rate of metabolism of cortical and epiphyseal bone are indicated by the uptake of radioactive tracer elements such as phosphorus and calcium (Manly \& Bale, 1939; Hevesy, Levi \& Rebbe, 1940; Manly, Hodge \& Manly, 1940; Armstrong \& Barnum, 1948). It is important to know how far these metabolic differences are paralleled, for example, by variations in degree of calcification of the organic matrix.

Baker, Butterworth \& Langley (1946) examined the calcium and nitrogen contents of cortical and cancellous bone from human femur and ribs. These authors paid particular attention to the methods used for cleaning the bones, interpreting earlier results (Booher \& Hansmann, 1931 ; Shear \& Kramer, 1928) in the light of their experience. They found that there was no significant difference between the calcium contents of the various adult bones; the mean value for all types examined was $25.5 \%$ (limiting values 24 and $27 \%$ ). The only difference between the nitrogen contents was a small but statistically significant one between the value for the cancellous bone of rib and of femur. The rib bones of babies contained significantly less calcium and more nitrogen than the bones from adults. Strobino \& Farr (1949) studied the distribution of nitrogen and ash in the radii, tibiae, humeri and ulnae from five cows and oxen of different ages. They found that a minimum value for nitrogen and a maximum for ash existed at the longitudinal midpoint of the bones. The degree of calcification of all the bones increased with age.

In the work to be described three types of bone from cats, rabbits and rats have been compared, namely cortical and cancellous bone from femur and alveolar bone surrounding the teeth. Calcium, phosphorus and nitrogen contents have been examined. The femoral bones were used so that our results might be compared with those of Baker et al. (1946). Alveolar bone has been examined because it 